Migration, Remittances and Rural Employment

Patterns: Evidence from China

\author{
Sylvie Démurger, Li Shi
}

October 2012 


\section{GATE Groupe d'Analyse et de Théorie Économique Lyon-St Étienne}

93, chemin des Mouilles 69130 Ecully - France

Tel. +33(0)4 72866060

Fax $+33(0) 472866090$

6, rue Basse des Rives 42023 Saint-Etienne cedex 02 - France

Tel. +33 (0)4 77421960

Fax. +33 (0)4 77421950

Messagerie électronique / Email : gate@gate.cnrs.fr

Téléchargement / Download : http://www.gate.cnrs.fr - Publications / Working Papers 


\title{
Migration, Remittances and Rural Employment Patterns: Evidence from China*
}

\author{
Sylvie Démurger ${ }^{\dagger} \quad$ Li Shi $^{\ddagger}$
}

October 19, 2012

\begin{abstract}
This paper explores the rural labor market impact of migration in China using crosssectional data on rural households for the year 2007. A switching probit model is used to estimate the impact of belonging to a migrant-sending household on the individual occupational choice categorized in four binary decisions: farm work, wage work, self-employment and housework. The paper then goes on to estimate how the impact of migration differs across different types of migrant households identified along two additional lines: remittances and migration history. Results show that individual occupational choice in rural China is responsive to migration, at both the individual and the family levels, but the impacts differ: individual migration experience favors subsequent local off-farm work, whereas at the family level, migration drives the left-behinds to farming rather than to off-farm activities. Our results also point to the interplay of various channels through which migration influences rural employment patterns.
\end{abstract}

JEL Codes: O15, J22, R23, D13, O53.

Keywords: labor migration, labor supply, remittances, temporary migration, left-behind, China.

\footnotetext{
${ }^{*}$ We are grateful to two anonymous referees for constructive comments and useful suggestions. All remaining errors and omissions are ours.

${ }^{\dagger}$ Université de Lyon, Lyon, F-69007, France; CNRS, GATE Lyon Saint-Etienne, 93 Chemin des Mouilles, Ecully, F-69130, France. Email: demurger@gate.cnrs.fr.

${ }^{\ddagger}$ School of Economics and Business Administration, Beijing Normal University, 19, Xinjiekouwai Dajie, Beijing 100875, China. Email: lishi@bnu.edu.cn.
} 


\section{Introduction}

Recent debates on China reaching the "Lewis turning point" (Fleisher et al., 2011; Knight et al., 2011) have highlighted changing trends in the Chinese labor market situation. As far as the rural labor market is concerned, Wang et al. (2011) underline a structural break in the 2000s when wage earning migration dramatically accelerated while rural self-employment stagnated ${ }^{1}$. Population movement across China started in the 1980s, but the outbreak of rural-to-urban migration took place in the 2000s (Meng et al., 2010) with millions of peasants flooding into cities. In 2011, the estimated number of migrant workers reached 158 million $^{2}$. Beyond these impressive figures, rural migration has also been widely recognized as playing a strategic role in the overall development process of China. On the one hand, rural migrants are key actors in the industrialization and urbanization process of China. On the other hand, as they maintain strong links with their home communities, they also play a leading role in rural development by adding a source of income diversification for sending regions. Many aspects of the urban life of rural migrants have been documented in the literature. Yet, there is still little empirical evidence on how migration and remittances affect individuals and households who stay behind.

The impact of migration on the non-migrating members of rural households can be explored through various channels. The most studied one internationally as well as for China is the income or welfare impact of migration and remittances on the left-behinds (see Yang (2011) for a survey). Tests of the impact of migration on incomes, production levels and investments in international migrant-sending areas include Taylor and Wyatt (1996) and Taylor and Lopez-Feldman (2010) on Mexico, Wouterse and Taylor (2008) on Burkina Faso or Atamanov and van den Berg (2012) on the Kyrgyz Republic. As for China, the existing studies show that migration and remittances affect crop production (Rozelle et al., 1999) and improve rural households' ability to cope with risk (Giles, 2006; Giles and Yoo, 2007), and that remittances partially compensate for a negative lost-labor effect and stimulate crop and possibly self-employment production (Taylor et al., 2003).

Yet, another channel of investigation is to examine the labor market behavior and outcome of household members who stay behind. The realm of existing literature on the impact of labor migration on rural labor allocation relies on two complementary approaches, the livelihood approach (Ellis, 1998) and the New Economics of Labor Migration (NELM) framework (Taylor, 1999). Fundamentals are very close to each other since migration can be considered as part of the rural household strategy to diversify income-generating activities and secure income in the case of failures in rural capital and labor markets. In the NELM framework, migration decision is taken by the entire household to maximize joint utility (Taylor and Martin, 2001). The impact of migration on local communities is then typically twofold: i) a loss in household

\footnotetext{
${ }^{1}$ They explain this change by a shrinking earnings-wage gap as the wage rate rose in the 2000s.

${ }^{2}$ Source: http://www.stats.gov.cn/english/pressrelease/t20120120 402787463.htm. This number refers to the rural labor force that has migrated for work out of their township of residential registration for at least 6 months in the year of investigation.
} 
labor that may have a negative impact on rural activities when rural labor market is imperfect and does not allow for hiring labor as a substitute to the departed family labor; ii) the transfer of remittances that can relieve credit and liquidity constraints and enable rural households to enter higher-return and more risky activities. Although remittances can attenuate the lost-labor effect by relaxing liquidity constraints, they may in turn reinforce the negative impact of the loss of labor if they dampen the incentives to work of the left-behinds. This may be the case if remittances raise the reservation wage of non-migrating members and decrease the opportunity cost of leisure (Amuedo-Dorantes and Pozo, 2006; Atamanov and van den Berg, 2012; Binzel and Assaad, 2011; Lokshin and Glinskaya, 2009). Therefore, the net impact of migration on rural employment patterns is not clear a priori and depends on the relative magnitudes of the separate channels. In addition, the impact is likely to be heterogeneous across households and to depend on a number of dimensions that will affect the magnitude of the lost-labor effect as well as the remittances-related effect. These additional dimensions include the age and gender profile of the remaining household members, their employment sectors (Atamanov and van den Berg, 2012), the seasonal or permanent nature of migration (Atamanov and van den Berg, 2012; Görlich and Trebesch, 2008), household's assets (Taylor and Wyatt, 1996; Wouterse and Taylor, 2008), as well as how binding liquidity constraints are for the household.

Formal models of the impact of migration on rural labor allocation include Taylor et al. (2003), Wouterse and Taylor (2008), and Lokshin and Glinskaya (2009). Taylor et al. (2003) propose a simple framework to illustrate the NELM hypothesis on the role of financial intermediaries that migrants play in enabling the migrant-sending households to overcome credit constraints. They distinguish between low-return activities and high-return activities and assume that investing in the latter is constrained because of incomplete markets for credit or insurance. In this setting, migration and remittances are further assumed to affect production constraints through the channels highlighted above: the credit-relaxing effects of remittances sent back by migrants come at the cost of a loss of labor that may constrain the rural household in a context of missing or imperfect labor market. Following a similar approach, Wouterse and Taylor (2008) explore the differentiated role of migration depending on migrant destination (continental versus inter-continental migration) and production activity (staple production, cash crop production, livestock production and non-farm production). They use a farm household model which specifically accounts for the lost-labor effect entailed in migration: if labor markets are imperfect, labor availability for local production and migration is constrained by household labor supply, which creates a trade-off between rural work and migration. The model also incorporates the possibility for migration to help relaxing the entry constraint into non-farm activities, where the constraint is modeled as a function of household assets that include migrants. Both models highlight the impact of migration as being multi-channeled, with an a priori indeterminate sign. Using data on Burkina Faso, Wouterse and Taylor (2008) find support of the NELM hypothesis: migration enables rural households to overcome binding entry barriers to high-return and 
low-intensive activities (livestock production in their case) but it has a negative impact on more labor intensive activities (non-farm and staple activities) due to the implied loss of household labor. Using data from a survey of 787 farm households from Hebei and Liaoning provinces of China in 1995, Taylor et al. (2003) find evidence that remittances sent home by migrants loosen constraint on crop production in migrant-sending households and partially compensate for the lost-labor negative effect on cropping income.

In a slightly different vein, Lokshin and Glinskaya (2009) propose a two-period model of utility maximization by a household composed of a husband and wife, which puts the emphasis on intrahousehold division of labor rather than on the removal of liquidity constraints. Occupational choices are made in sequence, with the husband first choosing to work on the local labor market or to migrate, and the wife then dividing her time between home production, market work and leisure. The model is based on the key assumption of different comparative advantages of the spouses, with the husband being more productive on the labor market and the spouse more productive at home. Under the assumptions of intra-household specialization and of a sequential choice, Lokshin and Glinskaya (2009) highlight the theoretically ambiguous impact of male migration on female labor market participation at home. Again, various forces compete. On the one hand, remittances sent by the husband have an disincentive effect on the wife's labor market participation by raising her reservation wage. On the other hand, the husband's migration may lower or increase the wife's productivity at home (and thereby affect her labor market participation) depending on whether the inputs of the spouses in the home production function are complements or substitutes. Using Nepalese data, Lokshin and Glinskaya (2009) find evidence of an overall negative impact of male migration on the labor market participation of women left behind. In line with this approach, Binzel and Assaad (2011) also find a decrease in wage work for women left behind in Egypt, a result they interpret as evidence of a higher reservation wage induced by remittance income ${ }^{3}$. The only increase of labor supply of women comes from increases in unpaid family work and subsistence work, particularly in rural areas.

This paper explores the question of how migration and rural occupational choice interact in China. To our knowledge, there are only two papers directly related to our analysis for the case of China: Mu and van de Walle (2011) and Chang et al. (2011). Using the same longitudinal dataset from the China Health and Nutrition Survey between 1997 and 2006, these studies provide complementary analyses on labor allocation of the left-behinds since $\mathrm{Mu}$ and van de Walle (2011) focus on women while Chang et al. (2011) focus on the elderly and children. Their common findings are that the left-behinds (women, elderly, children) are doing more farm work than would have otherwise been the case and that return migration does not seem to reverse the labor allocation changes. Mu and van de Walle (2011) also find little impact on women's health outcomes and no impact on their empowerment. Our approach differs from these studies

\footnotetext{
${ }^{3}$ As a matter of fact, the existing empirical literature on the labor supply responses of the left-behinds to migration highlights a decreasing labor force participation, especially for left-behind women (Amuedo-Dorantes and Pozo, 2006; Lokshin and Glinskaya, 2009; Mendola and Carletto, 2009; Binzel and Assaad, 2011).
} 
and contributes to the empirical literature testing for the impact of migration on sending areas on the following grounds. First, rather than focusing on a subset of household members, we adopt a broader approach and examine the labor supply responses of all non-migrant household members. Second, and most importantly, we try to disentangle the lost-labor versus remittances effects of migration by exploring the impact of migration through both remittances and household migration history. For this purpose, we exploit two key features of Chinese internal migration: i) it is a large-scale phenomenon that currently affects many households in rural China (current migration), and ii) it is largely of temporary nature (return migration). As a consequence, both current migration status of the family members and individual migration history may impact rural occupational choices, which is tested here by considering various indicators for migration status and history.

Our empirical analysis relies on cross-sectional data from the Rural Household Survey of the China National Bureau of Statistics for the year 2007. Identifying the impact of migration on rural labor allocation is not straightforward, in particular in a cross-section wherein reverse causality, endogenous selection and omitted variable biases are all potentially important problems (Antman, 2012). We apply a switching probit model as developed by Aakvik et al. (2005) and Lokshin and Glinskaya (2009) that allows us to estimate the impact of belonging to a migrantsending household on the individual occupational choice categorized in four binary decisions: farm work, wage work, self-employment and housework. The paper then goes on to estimate the role of remittances and of migration history for those migrant-sending households and presents a range of estimates corresponding to these additional dimensions, which shows how the impact of migration differs across different types of migrant households.

The rest of the paper is structured as follows. Section 2 describes the data on which the analysis is based. The empirical strategy is presented in Section 3. Estimation results follow in Section 4. Section 5 concludes.

\section{Migration and rural labor allocation in the Chinese context}

\section{$2.1 \quad$ Data}

We rely on cross-sectional data from the Rural Household Survey administered by the National Bureau of Statistics under the Rural-Urban Migration in China (RUMiC) project ${ }^{4}$ in 2008. The survey covers 8,000 rural households from 800 villages, in 82 counties and nine provinces (Hebei, Jiangsu, Zhejiang, Anhui, Henan, Hubei, Guangdong, Chongqing and Sichuan). It includes detailed information on individual labor market situation along with a wide range of household

\footnotetext{
${ }^{4}$ For details about the whole project and the survey design and implementation, see Meng et al. (2010). See also http://cbe.anu.edu.au/schools/eco/rumici/ for a map of the surveyed provinces and for survey questionnaires.
} 
and individual socio-economic characteristics. A village survey is also attached to the household survey. We restrict the individual sample to the working-age rural population (i.e. aged 16 to 60 ) who declared being working or unemployed (including housework). Retired people and students are excluded from the sample. The sample occupational distribution is given in Table $1^{5}$.

Concerning migration, there is no clear agreed-upon definition of a "migrant" in empirical studies on internal migration in China. In the official definition of the National Bureau of Statistics, a person is recorded as a migrant if she has left her registered place of residence in order to work for a certain period of time in a given year. This period of time was 6 months for the 2000 and the 2010 censuses, and one year for the 1990 census (Lin et al., 2004). In practice, the definition of migrants varies with the surveys used. For example, de Brauw et al. (2002) identified migrants as household members who have off-farm jobs but do not live in the household while working, without imposing any duration constraint. de Brauw and Rozelle (2008b) added a duration condition of three months or more to the above definition, and de Brauw and Giles (2008) considered "all registered village residents who work outside the home county". As for our own sample, we follow the NBS definition and identify migrants through the following criteria: a migrant in 2007 is a household member who works outside her home county and has been living away for at least 6 months. With this definition, migrants constitute $28 \%$ of the individual sample (see Table 1) and migrant-sending households constitute $44 \%$ of the 8,000 surveyed households.

The rural household questionnaire provides additional information on individual migration experience that is useful here. The individual records include whether the individual has ever migrated for work, and the year of first migration for work. Although the design of the question does not allow us to separate different sojourns that could have been interrupted by a temporary return, it enables us to classify migrants along a line of "early" or "late" migration experience. Migrants with an "early migration experience" are migrants whose maximum migration duration in 2007 was 7 years or more. Those who have been migrating for less than 7 years are classified as migrants with a "late migration experience". Finally, at the household level, the survey provides information about remittance income received in 2007, which allows us to further categorize households into households with or without remittance income.

\subsection{Summary statistics}

Table 1 presents the occupational distribution of the rural labor force by gender. Diversification of activities clearly appears with more than half of the individuals being involved in migration or in local non-farm activities. Unsurprisingly, men and women work patterns strongly differ ${ }^{6}$.

\footnotetext{
${ }^{5}$ Since the RUMiC survey does not provide information on working time allocation of the household members, we can only test the impact of migration on labor allocation and not on time allocation patterns as done in previous studies on China (Chang et al., 2011; Mu and van de Walle, 2011).

${ }^{6}$ The gendered household division of labor in rural China has been highlighted in a number of studies (e.g. Chang et al., 2011; de Brauw et al., 2008). Likewise, the intergenerational division of labor is documented in
} 
Housework is mostly done by women: $14 \%$ of women are engaged in housework against $2.5 \%$ of men. Half of women and $40 \%$ of men are employed in farming activities. In contrast, men are much more involved in off-farm work than women, both locally and as migrants. Gender differences in labor allocation are also obvious in self-employment, with men being more likely to be self-employed than women. Figure 1 illustrates how occupational distribution varies with age, for men and for women. As widely documented, rural migrants in China are found in the youngest cohorts for both men and women, with much higher shares for men up to the age of 35. In contrast, older age cohorts tend to be employed in agriculture. For middle-age cohorts, an interesting gender difference arises, which certainly reflects the higher incidence of migration among men: women aged 35 to 45 are much more likely to work in agriculture than men in the same age cohort ${ }^{7}$. Figure 1 also gives a first indication as to the potential intra-household division of labor, with work migration being predominantly a young male phenomenon while those remaining are mostly older and female labor, a feature that has also been documented in earlier studies (see e.g. Mu and van de Walle, 2011).

In 2007, 44\% of the surveyed households had at least one migrant member (for at least six months), and $46 \%$ of these households had migrants with early experience (seven years or above). The majority of households with migrant(s) received remittances in $2007(80 \%)^{8}$. Interestingly, $85 \%$ of the households with early-experienced migrants (as defined above) received remittances in 2007 , while only $76 \%$ of the households with late-experienced migrants received remittances in 2007. Table 2 and Table 3 document the relationship between remittances and the income profile of rural households. First, Table 2 shows that, although farm income still represents more than $40 \%$ of households' annual income in 2007 , off-farm income is highly remunerative for those households with income from a specific source. This is particularly the case for remittances: whereas remittances account for $21 \%$ of total income for the total sample, their income share for households with migrant members is twice higher ${ }^{9}$. Second, the distribution of households across per capita income quartiles presented in Table 3 shows that the share of households with migrants (in particular with early migration experience) is the smallest for the highest quartile of per capita income. If opportunities to enter higher-returns local economic activities (including off-farm jobs) is increasing in income and wealth, then richer households will have less incentive to send migrants to cities other things being equal ${ }^{10}$.

As a first step to the analysis of the impact of migration on rural labor allocation, Table de Brauw et al. (2008).

${ }^{7} \mathrm{Mu}$ and van de Walle (2011) find similar gender/age-related profiles.

${ }^{8}$ About $23 \%$ of the non-migrant-sending households nevertheless declared receiving remittances in 2007 . These remittances may have been sent by migrants who returned home in 2007 or by non-household-members (extended family for example).

${ }^{9}$ Family non-farming activities, which include self-employment, also turn out to be an important source of income for households involved in such activities: the derived annual income from family non-farming activities is as high as 6,386 yuan on average and accounts for $24.9 \%$ of total income.

${ }^{10}$ Using data from the end of 1990s, Du et al. (2006) find an inverted-U-shaped relationship between household income and the likelihood of migration. Hence, the most likely to migrate are households near the poverty line whereas the poorest and the richest have a lower probability to migrate. 
4 reports labor allocation across activities by gender according to the migration status of the household. Three different sets of household groups are considered: migrant-sending households (versus non-sending households), remittance-receiving households among migrant-sending households (versus non remittance-receiving households) and early-experienced-migrant households among migrant-sending households (versus late-experienced-migrant households). Rural employment patterns are fairly similar across the various groups of households defined by migration status. Both left-behind men and women in migrant-sending or remittance-receiving households work much more in farming and much less in local off-farm and self-employment activities than men and women in non migrant-sending or non remittance-receiving households ${ }^{11}$. A comparison between early-experienced-migrant households and late-experienced-migrant households points to a potential disincentive effect of early migration experience for men since men who stay behind in early-experienced-migrant households tend to work much less in off-farm activities than their counterparts in late-experienced-migrant households while being confined in both farming and housework.

\section{Estimation strategy}

To estimate the impact of migration and remittances on labor market participation of family members left behind, one needs to take into account the possibility of self-selection. Unobserved household characteristics might not only affect the likelihood of belonging to a migrant-sending household but also influence the individual decision on labor market participation. A recent literature on sample selection in the context of discrete outcomes highlights the advantages of using a switching probit model over alternative econometric techniques (Aakvik et al., 2005; Lokshin and Glinskaya, 2009; Ridao-Cano, 2001). Following this strand of literature, we thus consider a three-equation model that describes a regime determination rule and the regimespecific labor market behavior of an individual. In our case, the regime $\left(T_{i}\right)$ is whether the individual belongs to a migrant-sending household (and variants) or not and the (binary) outcome measure $\left(Y_{i}\right)$ is rural work participation.

This model of a binary choice with binary endogenous regressors can be written as follows:

$$
T_{i}= \begin{cases}1 & \text { if } \quad \gamma Z_{i}+\mu_{i}>0 \\ 0 & \text { otherwise }\end{cases}
$$

\footnotetext{
${ }^{11}$ This observation is corroborated by a comparison of rural household income sources by remittance-recipient status (not reported here). Participation rates in both local wage work activities and family non-farming activities are much lower for households with remittance income. On the other hand, many households without migrant transfers diversify their production into non-farm activities that provide them with a source of income uncorrelated with agriculture: this is true for both wage and non-wage work.
} 


$$
\begin{aligned}
Y_{1 i}^{*} & =I\left[\beta_{1} X_{1 i}+\epsilon_{1 i}>0\right] \\
Y_{0 i}^{*} & =I\left(\left[\beta_{0} X_{0 i}+\epsilon_{0 i}>0\right]\right.
\end{aligned}
$$

where $Y_{1 i}^{*}\left(\right.$ resp. $Y_{0 i}^{*}$ ) is the latent variable for the observed binary outcome $Y_{1}$ (resp. $Y_{0}$ ) in the migration state (resp. non-migration state); $Z_{i}$ and $X_{i}$ are vectors of observables generating the selection equation and the rural labor market participation; $\mu_{i}$ is the error term for the selection equation, $\epsilon_{1 i}$ and $\epsilon_{0 i}$ are the regime-specific error terms and $I[$.$] is the indicator function. The$ error terms $\left(\mu_{i}, \epsilon_{1 i}, \epsilon_{0 i}\right)$ are assumed to be jointly normally distributed with zero mean vector and covariance matrix ${ }^{12}$ :

$$
\Sigma=\left(\begin{array}{ccc}
1 & \rho_{\mu 1} & \rho_{\mu 0} \\
& 1 & \rho_{01} \\
& & 1
\end{array}\right)
$$

where $\rho_{\mu 1}$ (resp. $\left.\rho_{\mu 0}\right)$ is the correlation between the unobserved characteristics predicting migration participation $\mu$ and labor outcome in the migration state $\epsilon_{1}$ (resp. labor outcome in the non-migration state $\epsilon_{0}$ ), and $\rho_{01}$ is the correlation between $\epsilon_{0}$ and $\epsilon_{1}$. If the $\rho \mathrm{s}$ are significant, then accounting for selection is necessary to ensure unbiased and efficient estimates.

The general econometric framework for analyzing the impact of endogenous treatments on discrete outcomes has first been formulated by Aakvik et al. (2005). Following Lokshin and Glinskaya (2009), we estimate a switching probit model, which offers several advantages over alternative methods ${ }^{13}$. In particular, it enables controlling for selection in determining the labor market participation impact of migration and estimating an average treatment effect (ATE) as well as a treatment effect on the treated (ATT). It also allows the impact of observables and unobservables on the outcome to differ for the "treated" and the "untreated" populations.

We investigate the impact of migration on rural individual occupational choices through a series of variables that reflect different regimes of migration $T$ as well as different outcomes $Y$. As for the rural occupational outcomes, we consider separately four different categories of choice for $Y$ : domestic work, farming, local wage work and self-employment. As for the regimes $T$, we apply the following sequence of estimations. First, we take the regime to be whether the individual belongs to a migrant-sending household. Then, we confine the analysis to individuals belonging to migrant-sending households and we consider two additional dimensions: i) whether

\footnotetext{
${ }^{12} \mathrm{~A}$ complete description of the model and of the 'switch probit' Stata routine that estimates the model is provided in Lokshin and Sajaia (2011).

${ }^{13}$ Lokshin and Glinskaya (2009) provide a comprehensive discussion on the advantages of the different econometric approaches available (including instrumental variable regressions, bivariate probit estimators, and matching type estimators). A similar switching probit model has also been applied by Ridao-Cano (2001) who estimates the effect of working while in school on school progress in Bangladesh and by Carrasco (2001) in a study of women's labor force participation with endogenous fertility in the U.S.
} 
the individual belongs to a remittance-receiving household; ii) whether the individual belongs to a household with early-experienced migrants (as defined in section 2).

The model covariates in $X_{i}$ contain a series of factors expected to affect labor market participation. Individual characteristics include age, the square of age, gender, years of schooling, training, marital status, and individual migration experience. Family labor resources and human capital are accounted for through the household size and composition (the number of old and young dependent members) as well as dummy variables indicating whether the father and/or the mother of the household head holds an off-farm occupation. Household assets are measured by land endowment and the housing value. To account for differences in local labor market conditions across rural economies, a vector of county-level dummy variables is also introduced in the model. Means and standard deviations for the main explanatory variables are reported in Table 5 for both migrant-sending and non-sending households.

As with a recursive bivariate model, the system of equations (1) to (3) is identified by nonlinearities even if the vectors of observables $Z_{i}$ and $X_{i}$ overlap completely (Lokshin and Glinskaya, 2009). However, the use of instruments is generally advocated to make the results more robust to distributional misspecification. Such instruments are expected to influence migration decision, but not to affect the rural individual labor market participation (other than through their effect on migration). A wide body of the empirical literature uses migration networks as instruments for migration decision ${ }^{14}$ on the ground that information about potential jobs in cities or related costs can be easily shared in communities with a history of migration, hence reducing migration costs (Taylor et al., 2003). However, in our specific context, the exclusion restriction may be violated since a large network is likely to be correlated with features of the local economic environment that are themselves having a direct impact on the local occupational choice. In a comparison of different approaches to identifying the income impact of migration, McKenzie et al. (2010) show that using an instrument like migrant networks may lead to considerable bias whereas appropriate instruments can perform very well ${ }^{15}$. If instruments are to be used, they favor those proxying for labor demand in potential migrant destinations. As summarized in Antman (2012), a series of papers use variables linked to economic conditions in destination areas as instruments for measuring the impact of migration on the left-behinds (e.g. Amuedo-Dorantes et al., 2008, Antman, 2011, Yang, 2008). Based on this, we define an instrument that aims at capturing lagged wage conditions in migration destinations. We expect that an instrument that describes past economic conditions in potential destination cities will affect migrants' decision to migrate without influencing directly current rural occupational choice. As noted by Cortes (2012), wages are valid instruments if they are determined mostly by demand and not influenced by changes in supply from migrant-sending areas. In the China context, one may confidently assume that

\footnotetext{
${ }^{14}$ See Antman (2012) and de Brauw and Carletto (2012) for recent surveys on measuring and identifying the impact of migration on sending communities.

${ }^{15}$ This point has been rightly brought to our attention by a referee, whose constructive remarks are acknowledged here.
} 
this was the case in the early 2000s, before labor shortages started from 2004 onward.

To construct the instrumental variable, we use data extracted from the 2002 China Household Income Project (CHIP) survey on rural migrants. This survey provides detailed information on rural migrants earnings and working time for a set of 25 prefecture-level cities across 12 provinces (Anhui, Beijing, Gansu, Guangdong, Henan, Hubei, Jiangsu, Liaoning, Shanxi, Chongqing, Sichuan, and Yunnan $)^{16}$. Though the survey does not cover all the possible migration destinations in China, it was designed to be representative of the migrant population in 2002. One difficulty is that we do not know where rural migrants from the 2007 rural RUMiC survey are actually located. Rather than identifying a few cities as potential locations for each county of origin, we use a weighted average of all hourly wages available from the 25 possible destinations. As the distance between the county of origin and the city of destination may be an important factor in shaping migration patterns, we account for distance by defining, for each county of origin, an inverse-distance weighted average of migrant hourly wages over all cities ${ }^{17}$. The instrument is thus defined at the county level (and does not vary across villages). A potential concern is that given the small number of destination cities, there is insufficient variation. Summary statistics from the city-level data indicate that in 2002, the average hourly wage for migrants ranged from 1.81 yuan to 4.89 yuan, with a mean at 2.77 and a standard deviation of 0.75. Moreover, the matching with county-level data and the inverse-distance weighting should ensure additional variation across space.

\section{Migration and rural labor force participation}

\subsection{Estimation results}

In this section, we first discuss the estimated coefficients in the selection and outcome equations for a regime that distinguishes migrant-sending and non migrant-sending households. As we consider four different binary choice models for labor market outcome, estimates of the respective parameters are reported in Tables 6 to 9. Each table reports estimates of the selection equation and labor participation outcomes contingent on migrant-sending or non-migrant-sending decision.

The determinants of rural occupational choice identified in these tables are consistent with usual findings of the empirical literature on rural labor allocation. Amongst individual characteristics, there are significant gender differences in occupational choice. Men are more likely

\footnotetext{
${ }^{16}$ The China Household Income Project is an internationally joint research project established in 1987, and coordinated by the Institute of Economics, Chinese Academy of Social Sciences, with assistance from the National Bureau of Statistics (NBS). It includes three waves: 1988, 1995, and 2002 that have been widely used to investigate income inequality in China. The main novelty of the 2002 survey was that it included a specific questionnaire dedicated to rural-urban migrants living in cities. A detailed description of the survey can be found in Li et al. (2008).

${ }^{17}$ Distances between each pair of county/city are calculated using latitude and longitude data for every county and city.
} 
to engage in both wage work and self-employment and are less likely to undertake household chores than women are, holding other variables constant. In contrast, there is no significant gender difference in farm work participation. Consistent with a life-cycle hypothesis, the level of off-farm participation increases with age up to a threshold level of about 40-45 years old. Years of education and training also increase the probability to engage in off-farm work, and significantly reduce the propensity to do domestic work or to work on farm. Interestingly, the marital status affects rural labor allocation differently, depending on the migration status of the household. In particular, farm work participation is found to be higher for married individuals in households with migrants but smaller in households without migrants. On the other hand, being married significantly increases the probability to be self-employed for individuals in non-migrant sending households. These results may reflect some "intra-household specialization" (Hanson, 2007; Lokshin and Glinskaya, 2009). For households who do not receive external sources of income through remittances, the diversification strategy rests upon spouses who work less on farm and more as self-employed. Finally, individual past migration experience clearly increases the likelihood to engage in off-farm work and reduces the probability to engage in farm labor. This finding confirms that return migrants are more likely to opt for non-farm work once back to their village and that they do not return to farming (Démurger and $\mathrm{Xu}, 2011 \mathrm{~b}$ ). In this respect, migration positively contributes to the development of off-farm activities in the countryside.

The impact of observed family characteristics on rural off-farm participation only marginally differs between migrant-sending and non-sending households. Household size, composition and assets all have a strongly significant effect on wage work choice, but almost no effect on selfemployment or farm work. Interestingly, household wealth, measured through the housing value, is associated with a higher propensity to work off-farm (both as a wage worker or a self-employed) and a lower probability to do farming for individuals in households without migrants. On the other hand, individuals in households with larger farm land are more likely to work on farm and less likely to engage in wage work or self-employment.

Results from the selection equation are qualitatively consistent with the migration literature on China. Households that are larger, with fewer old and young dependent members and less wealthy are more likely to be migrant-sending compared to their smaller, with more dependent members and wealthier counterparts. Moreover, whether the father or the mother of the household head holds an off-farm position reduces the household's probability to send migrants to cities. Finally, Wald tests show that the null hypothesis of $\rho_{\mu 0}=\rho_{\mu 1}$ can be rejected for wage work participation only but it is not rejected for the other outcomes. This means that unobservables in the selection equation are not apparently correlated with unobservables in the outcome equations, except for wage work. Regarding wage work outcome, the estimated $\rho_{\mu 0}$ (0.893) indicates a positive correlation between the unobserved characteristics that predict selection into migration and wage work outcome among individuals in non-sending households. Put differently, the unobserved factors (risk aversion for example) that predict a higher propensity 
for households to send migrants also predict higher wage work among individuals in non-migrant sending households.

\subsection{Mean treatment parameters}

After discussing the estimated coefficients, we now present the estimated mean treatment parameters as shown in Table 10. The effect of migration on rural labor force participation, using the switching probit, is obtained through the average treatment effect (ATE) and the average treatment on the treated (ATT) as detailed in Lokshin and Glinskaya (2009) and Lokshin and Sajaia (2011). The ATE is the average effect on the probability of working in a specific occupation by an individual randomly selected from the rural population. The obtained value of 0.197 for farming indicates that a randomly-selected individual would have approximately $20 \%$ higher probability of working on farm if she had a migrant in her household. Interestingly, when we move to individuals who actually belong to migrant-sending households, the ATT is smaller at $0.155^{18}$. This suggests that though individuals in migrant-sending households are indeed more likely to work on farm than if they did not have migrants in their household, individuals who are more likely to work on farm are not those most likely to belong to a migrant-sending household. Hence, controlling for selection is critical in estimating the impact of migration on farm work. A potential explanation would be a small lost-labor effect for migrant-sending households, which is supported by the selection equation that indicates that larger households with fewer dependent members are more likely to be migrant-sending (see Table 6$)^{19}$. To investigate further this point, we run separate estimations for women and for men since there might be a gender effect in farm work. We do in fact find strong differences in the ATE and ATT for men and for women. In particular, we find that women in migrant-sending households are more likely to work on farm than randomly-selected women. The increased farm work due to migration (and a concomitant lost-labor effect) is stronger when women rather than men are left-behind. This may be explained by the fact that men are working more on the farm anyway and as a consequence, the lost-labor effect of migration is stronger when men are leaving (and women left behind). This finding is in line with $\mathrm{Mu}$ and van de Walle (2011) evidence of an increase in agricultural work by women left behind.

Unsurprisingly, the average treatment effect (ATE) and the treatment effect on the treated (ATT) for rural wage work participation are found to be negative, at -0.249 and -0.609 respectively. These findings indicate that for the entire population of the rural left-behind, sending a migrant to city reduces the probability to participate in local wage-work, but that the reduction is far greater for those individuals who actually live in a migrant-sending household (as compared to the counterfactual of individuals living in a non-migrant sending household). This

\footnotetext{
${ }^{18}$ In comparison, the raw difference in mean farm work participation is 0.182 (see Table 4).

${ }^{19}$ Morover, the temporary feature of internal migration in China may make the lost-labor effect in farming less binding, or less prominent, if migrants regularly return home for seasonal contributions.
} 
finding may illustrate a trade-off between migration and local off-farm work that can be related to a combination of both a remittance-related effect and a lost-labor effect of migration. On the one hand, the negative impact of migration on local off-farm work may reflect a smaller demand for diversification when a migrant sent to city plays an insurance role for the rural household. This is consistent with the risk-coping benefits from off-farm employment found by Giles (2006). On the other hand, in the specific Chinese context, sending a migrant to city not only reduces the available labor force for farming, but may also further constrain the household diversification strategy. Indeed, since land is not privately owned, farmers cannot afford leaving land unexploited without taking the risk of having their land-use rights seized for reallocation ${ }^{20}$. With a reduced amount of labor force left in the rural sector and almost no market for hiring agricultural labor to substitute for family labor, rural households face a trade-off in their income-generating activities diversification strategy, which may explain a smaller participation in local off-farm work for migrant-sending households.

As for self-employment participation, Table 10 also highlights negative effects: the average treatment effect (ATE) and the treatment effect on the treated (ATT) are found to be -0.087 and -0.156 respectively. Hence, a randomly-selected individual would have approximately 16 percentage points lower probability of being self-employed if she had a migrant in her household and 9 percentage points lower probability for an individual actually belonging to a migrant-sending household. The negative impact of migration on self-employment participation may appear somewhat surprising if one expects migration to effectively contribute to the alleviation of the liquidity constraint for rural households. However, it is consistent with the evidence presented by de Brauw and Rozelle (2008a) on the absence of a relationship between migration and productive investment in rural China. What our finding suggests here is that while self-employment participation increases with individual migration experience (see Table 8), it is negatively affected by the current migrant situation of the family. Hence, it is likely that remittances sent by current migrants are used for consumption purposes rather than for productive purposes, as suggested by de Brauw and Rozelle (2008a). Moreover, the same mix of a remittance-related effect and a lost-labor effect of migration that applies to rural wage work participation may apply to self-employment participation.

Finally the impact of migration on housework reported in Table 10 is very small, but somehow surprisingly negative. The estimated ATT suggests a $0.5 \%$ lower probability to stay home for individuals who belong to a migrant-sending household. Here again, gender differences might be important. And indeed, running separate estimations for men and for women shows that women in migrant-sending households are significantly more likely to do household chores than randomly-selected women. The higher probability for housework for left-behind women may be explained in the China context by important administrative and financial barriers that deeply

\footnotetext{
${ }^{20}$ The issue of land rights insecurity in rural China has been widely documented. A comprehensive description is given in Brandt et al. (2002). Mullan et al. (2011), de la Rupelle et al. (2009) and Giles and Mu (2012) all show that land tenure insecurity reduces migration.
} 
constrain the migration of a whole family. As a consequence, migrant children are often left behind in the home village as long as they are enrolled in the education system, and looked after either by one parent (mostly their mother) or by grandparents or relatives (Démurger and $\mathrm{Xu}$, 2011a). Hence, sending a migrant to city may increase the need for home production that falls on the women left behind.

\subsection{The role of remittances and migration history}

In this part we confine the analysis to individuals in migrant-sending households and compare first, whether receiving remittances makes a difference and second, whether individuals in households with early-experienced migrants behave differently. As previously, we estimate a switching probit model where two new regimes are considered: first, whether the individual belongs to a remittance-receiving household; second, whether the individual belongs to a household with early-experienced migrant(s). To save space, we do not report the eight binary choice models for labor market outcome and we focus on the estimated mean treatment parameters as reported in Table 10.

Investigating further the income effect of remittances, we find that for the entire population of the left-behinds, receiving remittances slightly increases the probability of farm work (by 2 percentage points) and decreases the probability of local wage work (by 12.7 percentage points) or self-employment (by 2 percentage points). The negative effect on wage work is substantially greater for those individuals who actually live in a remittance-receiving household (as compared to the counterfactual of individuals living in a non-receiving household). Interestingly, we find a positive impact of remittances on housework: the estimated ATT at 0.022 suggests a $2.2 \%$ higher probability to stay home for individuals who belong to a remittance-receiving households. Compared to the estimated impact of migration, the positive ATT indicates a potential increase in the reservation wage of the left-behinds who receive remittances, thus leading to a disincentive to work. Hence, the estimated average treatment effects of receiving remittances support the hypothesis of remittance-related effects that lift budget constraints and possibly increase reservation wages. More specifically, these findings provide interesting insights on how the left-behinds labor supply responds to the receipt of remittances. On the one hand, we find support of an income effect that coincides with a reduced off-farm work effort. On the other hand, it does not seem to fully compensate for the lost-labor effect of migration for farm work and the allocation of labor supply is still skewed towards farm activities.

Regarding migration experience, one may conjecture that if a migrant has been away for more than 7 years, the disruptive effect for the left-behind family may be smaller as time passes. The lost-labor effect may then be attenuated if the household has reallocated labor so as to compensate for the foregone labor force. We do find some support for this assertion for farm work participation as well as for self-employment participation. Indeed, the average treatment 
effects for these choices have an opposite sign compared to the treatment effects computed from the migration regime: the effect of an early experience in migration for a left-behind individual randomly selected from the population is negative on farm work and positive on self-employment participation. These findings illustrate the complex relationship between migration and rural employment patterns by highlighting the time dimension of adjustments in rural labor allocation and rural income-generating activities. On the one hand, the lost-labor effect of migration seems to attenuate over time (and conversely may be especially disruptive during the first years of migration). On the other hand, the impact of remittances may change with migration duration ${ }^{21}$. The relaxation of liquidity constraint brought by migration and remittance income may not immediately turn into investment in productive activities and it may require some time before its effect is visible on the development of off-farm activities, notably on self-employment. Our findings of a positive impact of an early experience in migration on self-employment participation may probably be interpreted in this way.

\section{Conclusion}

This paper explores the rural labor market impact of migration in China using cross-sectional data on rural households for the year 2007. As highlighted in the New Economics of Labor Migration (NELM) literature, the global net effect of migration on the diversification of incomegenerating activities in sending communities is theoretically uncertain. The ambiguity stems from the interplay of various effects that can be broadly grouped into a lost-labor effect on the one hand, and a remittances-related effect on the other hand. In a typical neo-classical model of migration, migration competes with other household activities by reducing the supply of the household labor in the countryside. As a consequence, the induced lost-labor effect may increase the time devoted to farming by the left-behinds. Moreover, by contributing to the income of the left-home family, remittances sent by migrants are a means to secure income and overcome credit or liquidity constraints of rural households. In that case, migration can be viewed as a substitute to incomplete insurance or credit markets, with an undetermined impact on diversification. On the one hand, remittances may enable rural households to invest locally in more risky activities including self-employment (Stark, 1991), and as a consequence crowd out farming activities. On the other hand, migration itself can be part of the household diversification strategy and remittances -that are uncorrelated with agriculture shocks- may have a disincentive effect on rural members to engage in alternative off-farm work as an income-insurance strategy. Therefore, the overall net effect of migration on rural occupational choice at the household level remains an open empirical question.

\footnotetext{
${ }^{21}$ The duration of absence and remittances are obviously linked. However, whether remittances rise or fall with migration duration is a debated issue (Stark, 2009). With time spent in cities, migrants may earn higher income and then afford higher amount of transfers. Yet, their commitment to their family left behind may reduce over time, leading to an "out of sigh, out of mind" effect.
} 
Our main findings indicate that individual occupational choice in rural China is responsive to migration experience, at both the individual and the family levels. The key results are twofold. First, individual migration experience is found to be positively correlated to local off-farm work, which confirms that return migrants are more likely to opt for non-farm work once back to the village and that they do not return to farming (Démurger and $\mathrm{Xu}, 2011 \mathrm{~b}$ ). Hence, by enabling individuals to shift to higher-return activities, temporary rural-to-urban migration in China contributes to the development of off-farm activities in the countryside through the flow of return migrants. Second, and as important, we find that the overall effect of sending a migrant to city is to drive the left-behinds to farming rather than to off-farm activities. This second major result points to the ambiguous impact of migration on the family left behind and corroborates in particular Mu and van de Walle (2011)'s finding on left-behind women being left behind farming.

Our results illustrate the complex relationship between migration and rural labor allocation. First, they highlight differentiated impacts of current migration status of the family members and of individual migration history: at the family level, migration and local off-farm work substitute rather than complement, while at the individual level, migration experience favors subsequent local off-farm work. Such findings could have important implications in the light of the changing generations of migrants in China. In particular, as the younger generation of migrants, born in the 1980s, more urbanized and less obedient, is not willing to return back to their home village as their parents $\mathrm{do}^{22}$, our results indicate that rural development may lag behind in the future if the left-behinds reallocate to farming while returning migrants no longer drive non-farm activities. Second, our analysis points to various channels through which migration influences rural employment patterns. We find mild evidence of a lost-labor effect whose magnitude varies with the activity. For farm choice, it is small on average, but we highlighted gender differences that result in a stronger effect when men rather than women are leaving. For local off-farm choice, we found evidence of a trade-off that indicates that migration and local wage work probably compete for labor force, and as a result, are substitutes in the household diversification strategies. Regarding the remittance-related effect, our findings indicate that migration may increase the reservation wage of those left behind, which translates into a disincentive to work. Moreover, we find no evidence of a productive use of remittances that would foster the development of self-employed activities for example.

The analysis of the role of remittances and of migration early experience highlights further dimensions to consider in the relationship between migration and rural labor allocation. Belonging to a migrant household with remittance income reduces off-farm work effort, but the supposedly important income effect does not fully compensate for the lost-labor effect for farm activity. In contrast, belonging to a migrant household with early-experienced migrants reduces

\footnotetext{
${ }^{22}$ A survey conducted by the Chinese Academy of Social Sciences in spring 2011 in 60 enterprises in Chongqing and Tianjin, and covering 1,200 workers reports that "only 17 percent of the young migrant workers surveyed (aged 24 and under) were willing to return home if they could not survive in cities. More than 80 percent of these young migrant workers wanted to stay in cities no matter what happened to them." (China Daily, 22 July 2011).
} 
the disruptive effect of the lost labor and increases off-farm participation. Hence, although in the short run, the net effect of migration seems to lead to a reduction of off-farm participation and an increase in farming, in the long run, migration may contribute to a shift of the rural labor force from the farm sector to the off-farm sector. 


\section{References}

Aakvik, A., Heckman, J., and Vytlacil, E. J. (2005). Estimating treatment effects for discrete outcomes when responses to treatment vary: An application to Norwegian vocational rehabilitation programs. Journal of Econometrics, 125(1-2):15-51.

Amuedo-Dorantes, C., Georges, A., and Pozo, S. (2008). Migration, remittances and children's schooling in Haiti. IZA Discussion Paper No. 3657.

Amuedo-Dorantes, C. and Pozo, S. (2006). Migration, remittances, and male and female employment patterns. American Economic Review, 96(2):222-226.

Antman, F. (2011). The intergenerational effects of paternal migration on schooling and work: What can we learn from children's time allocations? Journal of Development Economics, 96(2):200-208.

Antman, F. (2012). The impact of migration on family left behind. IZA Discussion Paper No. 6374 .

Atamanov, A. and van den Berg, M. (2012). Heterogeneous effects of international migration and remittances on crop income: Evidence from the Kyrgyz Republic. World Development, 40(3):620-630.

Binzel, C. and Assaad, R. (2011). Egyptian men working abroad: Labour supply responses by the women left behind. Labour Economics, 18, Supplement 1(0):S98-S114.

Brandt, L., Huang, J., Li, G., and Rozelle, S. (2002). Land rights in China: Facts, fictions and issues. The China Journal, 47:67-97.

Carrasco, R. (2001). Binary choice with binary endogenous regressors in panel data: Estimating the effect of fertility on female labor participation. Journal of Business and Economic Statistics, 19(4):385-394.

Chang, H., Dong, X., and MacPhail, F. (2011). Labor migration and time use patterns of the left-behind children and elderly in rural China. World Development, 39(12):2199-2210.

Cortes, P. (2012). The feminization of international migration and its effects on the children left behind: Evidence from the Philippine. Boston University - School of Management.

de Brauw, A. and Carletto, C. (2012). Improving the measurement and policy relevance of migration information in multi-topic household surveys. Living Standards Measurement Study Working Paper 14, Washington DC, The World Bank.

de Brauw, A. and Giles, J. (2008). Migrant opportunity and the educational attainment of youth in rural China. Policy Research Working Paper 4526, Washington DC, The World Bank.

de Brauw, A., Huang, J., Rozelle, S., Zhang, L., and Zhang, Y. (2002). The evolution of China's rural labor market during the reforms. Journal of Comparative Economics, 30(2):353-529.

de Brauw, A., Li, Q., Liu, Q., Rozelle, S., and Zhang, L. (2008). Feminization of agriculture in China? Myths surrounding women's participation in farming. The China Quarterly, 194:327348.

de Brauw, A. and Rozelle, S. (2008a). Migration and household investment in rural China. China Economic Review, 19(2):320-335.

de Brauw, A. and Rozelle, S. (2008b). Reconciling the returns to education in off-farm wage employment in rural China. Review of Development Economics, 12(1):57-71.

de la Rupelle, M., Deng, Q., Li, S., and Vendryes, T. (2009). Land rights insecurity and temporary migration in rural China. IZA Discussion Paper No. 4668.

Démurger, S. and Xu, H. (2011a). Left-behind children and return decisions of rural migrants in China. GATE Working Paper No. 1122. 
Démurger, S. and Xu, H. (2011b). Return migrants: The rise of new entrepreneurs in rural China. World Development, 39(10):1847-1861.

Du, Y., Park, A., and Wang, S. (2006). Migration and rural poverty in China. Journal of Comparative Economics, 33(4):688-709.

Ellis, F. (1998). Household strategies and rural livelihood diversification. Journal of Development Studies, 35(1):1-38.

Fleisher, B. M., Fearn, R., and Ye, Z. (2011). The Lewis model applied to China: Editorial introduction to the symposium. China Economic Review, 22(4):535-541.

Giles, J. (2006). Is life more risky in the open? Household risk-coping and the opening of China's labor markets. Journal of Development Economics, 81(1):25-60.

Giles, J. and Mu, R. (2012). Village political economy, land tenure insecurity and the rural to urban migration decision: Evidence from China.

Giles, J. and Yoo, K. (2007). Precautionary behavior, migrant networks, and household consumption decisions: An empirical analysis using household panel data from rural China. Journal of Development Economics, 89(3):534-551.

Görlich, D. and Trebesch, C. (2008). Seasonal migration and networks - Evidence on Moldova's labour exodus. Review of World Economics, 144(1):107-133.

Hanson, G. H. (2007). Emigration, remittances, and labor force participation in Mexico. Integration and Trade Journal, 27:73-103.

Knight, J., Deng, Q., and Li, S. (2011). The puzzle of migrant labour shortage and rural labour surplus in China. China Economic Review, 22(4):585-600.

Li, S., Luo, C., Wei, Z., and Yue, X. (2008). The 1995 and 2002 household surveys: Sampling methods and data description. In Gustafsson, B., Li, S., and Sicular, T., editors, Inequality and Public Policy in China, pages 337-353. Cambridge University Press.

Lin, J. Y., Wang, G., and Zhao, Y. (2004). Regional inequality and labor transfers in China. Economic Development and Cultural Change, 52(3):587-603.

Lokshin, M. and Glinskaya, E. (2009). The effect of male migration on employment patterns of women in Nepal. The World Bank Economic Review, 23(3):481-507.

Lokshin, M. and Sajaia, Z. (2011). Impact of interventions on discrete outcomes: Maximum likelihood estimation of the binary choice models with binary endogenous regressors. The Stata Journal, 11(3):368-385.

McKenzie, D., Gibson, J., and Stillman, S. (2010). How important is selection? Experimental versus non-experimental measures of the income gains from migration. Journal of the European Economic Association, 8(4):913-945.

Mendola, M. and Carletto, G. (2009). International migration and gender differentials in the home labor market: Evidence from Albania. Policy Research Working Paper 4900, Washington DC, The World Bank.

Meng, X., Manning, C., Li, S., and Effendi, T. N. (2010). The Great Migration: Rural-Urban Migration in China and Indonesia. Edward Elgard, Cheltenham.

$\mathrm{Mu}, \mathrm{R}$. and van de Walle, D. (2011). Left behind to farm? Women's labor re-allocation in rural China. Labour Economics, 18(S1):S83-S97.

Mullan, K., Grosjean, P., and Kontoleon, A. (2011). Land tenure arrangements and rural-urban migration in china. World Development, 39(1):123-133.

Ridao-Cano, C. (2001). Evaluating the impact of working while in school on school progress: The case of rural Bangladesh. Working Paper 01-17, University of Colorado at Boulder. 
Rozelle, S., Taylor, J., and de Brauw, A. (1999). Migration, remittances and agricultural productivity in China. American Economic Review, 89(2):287-291.

Stark, O. (1991). The migration of labor. Basil Blackwell, Cambridge, MA.

Stark, O. (2009). Reasons for remitting. World Economics, 10(3):147-157.

Taylor, J. (1999). The new economics of labour migration and the role of remittances in the migration process. International Migration, 37(1):63-88.

Taylor, J. and Lopez-Feldman, A. (2010). Does migration make rural households more productive? Evidence from Mexico. Journal of Development Studies, 46(1):68-90.

Taylor, J. and Martin, P. (2001). Human capital: Migration and rural population change. In Gardener, B. and Rausser, G., editors, Handbook of Agricultural Economics, volume 1, pages 457-511. Elsevier, Amsterdam.

Taylor, J., Rozelle, S., and de Brauw, A. (2003). Migration and incomes in source communities: A new economics of migration perspective from China. Economic Development and Cultural Change, 52(1):75-101.

Taylor, J. and Wyatt, T. (1996). The shadow value of migrant remittances, income and inequality in a household-farm economy. Journal of Development Studies, 32(6):899-912.

Wang, X., Huang, J., Zhang, L., and Rozelle, S. (2011). The rise of migration and the fall of self employment in rural China's labor market. China Economic Review, 22(4):573-584.

Wouterse, F. and Taylor, J. E. (2008). Migration and income diversification: Evidence from Burkina Faso. World Development, 36(4):625-640.

Yang, D. (2008). International migration, remittances and household investment: Evidence from Philippine migrants' exchange rate shocks. The Economic Journal, 118:591-630.

Yang, D. (2011). Migrant remittances. Journal of Economic Perspectives, 25(3):129-152. 
Table 1: Occupational distribution by gender

\begin{tabular}{lccc}
\hline \hline Occupation & Women & Men & Total \\
\hline Housework & 13.92 & 2.54 & 8.17 \\
Farming & 50.04 & 39.61 & 44.77 \\
Local wage work & 11.28 & 16.82 & 14.08 \\
Self-employed & 3.23 & 7.09 & 5.18 \\
Migrant & 21.52 & 33.95 & 27.79 \\
\# Obs. & 10,237 & 10,440 & 20,677 \\
\hline \hline
\end{tabular}

Source: RUMiC rural household survey 2007. Individuals aged 16 to 60 years. 
Table 2: Household income by source, 2007

\begin{tabular}{|c|c|c|c|c|c|}
\hline & \multirow[t]{2}{*}{$\begin{array}{c}\text { Mean } \\
\text { (Sd. Dev.) }\end{array}$} & \multirow[t]{2}{*}{$\begin{array}{l}\text { Share in } \\
\text { total income }\end{array}$} & \multirow{2}{*}{$\begin{array}{l}\% \text { of households } \\
\text { with income } \\
\text { from the source }\end{array}$} & \multicolumn{2}{|c|}{$\begin{array}{l}\text { Households with income } \\
\text { from that source: }\end{array}$} \\
\hline & & & & Mean & $\begin{array}{c}\text { Share in } \\
\text { total income }\end{array}$ \\
\hline Total income (in yuan) & $\begin{array}{c}19,451 \\
(15,967)\end{array}$ & & & & \\
\hline Per capita income & $\begin{array}{c}5,236 \\
(4,329)\end{array}$ & & & & \\
\hline Farm income & $\begin{array}{c}6,686 \\
(8,681)\end{array}$ & 41.8 & 95.5 & 7,003 & 43.7 \\
\hline Wage income & $\begin{array}{c}8,819 \\
(10,157)\end{array}$ & 42.4 & 86.4 & 10,206 & 49.1 \\
\hline Local wage work & $\begin{array}{c}3,957 \\
(7,532)\end{array}$ & 18.4 & 62.6 & 6,320 & 29.4 \\
\hline Remittances & $\begin{array}{c}4,061 \\
(7,179)\end{array}$ & 20.6 & 47.9 & 8,468 & 42.9 \\
\hline Family non-farm income & $\begin{array}{c}2,388 \\
(8,908)\end{array}$ & 9.3 & 37.4 & 6,386 & 24.9 \\
\hline \multicolumn{6}{|l|}{ Other income } \\
\hline Property income & $\begin{array}{c}654 \\
(5,822)\end{array}$ & 1.7 & 38.8 & 1,684 & 4.4 \\
\hline Transfer income & $\begin{array}{c}904 \\
(3,236)\end{array}$ & 4.8 & 76.3 & 1,185 & 6.3 \\
\hline
\end{tabular}

Source: RUMiC rural household survey 2007.

Notes: The total number of households is 8,000 ..

Table 3: Distribution of households across per capita income quartiles, 2007

\begin{tabular}{lccccc}
\hline \hline \% of households & $1^{\text {st }}$ quartile & $2^{\text {nd }}$ quartile & $3^{\text {rd }}$ quartile & $4^{\text {th }}$ quartile & Obs. \\
\hline With migrant(s) in 2007 & 27.80 & 29.07 & 26.27 & 16.85 & 3,471 \\
with late experience & 25.80 & 29.33 & 26.98 & 17.90 & \\
with early experience & 30.14 & 28.77 & 25.45 & 15.63 & \\
Without migrant(s) in 2007 & 22.85 & 21.88 & 24.02 & 31.24 & 4,529 \\
Total & & & & & 8,000 \\
\hline \hline
\end{tabular}

Source: RUMiC Rural Household Survey 2007.

Notes: Migrants with "early experience" are migrants whose total migration duration is 7 years or above. 
Table 4: Rural occupation distribution by gender and household migration status

\begin{tabular}{|c|c|c|c|c|c|c|}
\hline \multirow[b]{2}{*}{ Occupation } & \multicolumn{3}{|c|}{$\begin{array}{l}\text { Migrant-sending } \\
\text { household }\end{array}$} & \multicolumn{3}{|c|}{$\begin{array}{c}\text { Non migrant-sending } \\
\text { household }\end{array}$} \\
\hline & Women & Men & Total & Women & Men & Total \\
\hline Housework & 17.73 & 4.13 & 12.18 & 17.74 & 3.71 & 10.83 \\
\hline Farming & 73.31 & 74.06 & 73.61 & 57.48 & 53.35 & 55.45 \\
\hline Local wage work & 6.86 & 15.13 & 10.24 & 19.33 & 30.31 & 24.74 \\
\hline Self-employed & 2.10 & 6.68 & 3.97 & 5.45 & 12.63 & 8.99 \\
\hline \multirow[t]{2}{*}{ \# Obs. } & 3,192 & 2,201 & 5,393 & 4,842 & 4,695 & 9,537 \\
\hline & \multicolumn{3}{|c|}{$\begin{array}{c}\text { Remittance-receiving } \\
\text { household }\end{array}$} & \multicolumn{3}{|c|}{$\begin{array}{c}\text { Non remittance-receiving } \\
\text { household }\end{array}$} \\
\hline Occupation & Women & Men & Total & Women & Men & Total \\
\hline Housework & 16.44 & 4.49 & 11.64 & 22.83 & 2.87 & 14.24 \\
\hline Farming & 75.90 & 75.09 & 75.57 & 63.04 & 70.43 & 66.22 \\
\hline Local wage work & 6.00 & 14.18 & 9.29 & 10.25 & 18.48 & 13.79 \\
\hline Self-employed & 1.65 & 6.24 & 3.50 & 3.88 & 8.21 & 5.75 \\
\hline \# Obs. & 2,548 & 1,714 & 4,262 & 644 & 487 & 1,131 \\
\hline
\end{tabular}

"Early-experienced" migrant "Late-experienced" migrant household household

\begin{tabular}{lcccccc} 
Occupation & Women & Men & Total & Women & Men & Total \\
\hline Housework & 19.32 & 4.67 & 14.34 & 16.47 & 3.87 & 10.76 \\
Farming & 73.04 & 77.34 & 74.50 & 73.52 & 72.44 & 73.03 \\
Local wage work & 6.44 & 13.46 & 8.83 & 7.20 & 15.95 & 11.16 \\
Self-employed & 1.20 & 4.53 & 2.34 & 2.81 & 7.74 & 5.04 \\
\# Obs. & 1,413 & 728 & 2,141 & 1,779 & 1,473 & 3,252 \\
\hline \hline
\end{tabular}

Source: RUMiC rural household survey 2007. Individuals aged 16 to 60 years (excluding current migrants in 2007). 
Table 5: Summary statistics for explanatory variables

\begin{tabular}{|c|c|c|c|}
\hline & $\begin{array}{c}\text { Households } \\
\text { without migrant }\end{array}$ & $\begin{array}{l}\text { Households } \\
\text { with migrants }\end{array}$ & Total \\
\hline \multirow[t]{2}{*}{ Male } & 0.492 & 0.408 & 0.462 \\
\hline & $(0.500)$ & $(0.492)$ & $(0.499)$ \\
\hline \multirow[t]{2}{*}{ Age } & 41.50 & 46.17 & 43.19 \\
\hline & $(11.58)$ & $(10.39)$ & $(11.39)$ \\
\hline \multirow[t]{2}{*}{ Education } & 7.651 & 7.018 & 7.427 \\
\hline & $(2.554)$ & $(2.432)$ & $(2.529)$ \\
\hline \multirow[t]{2}{*}{ Training } & 0.223 & 0.151 & 0.197 \\
\hline & $(0.416)$ & $(0.358)$ & $(0.398)$ \\
\hline \multirow[t]{2}{*}{ Married } & 0.864 & 0.922 & 0.885 \\
\hline & $(0.343)$ & $(0.269)$ & $(0.319)$ \\
\hline \multirow[t]{2}{*}{ Past ind. migration } & 0.145 & 0.127 & 0.138 \\
\hline & $(0.352)$ & $(0.333)$ & $(0.345)$ \\
\hline \multirow[t]{2}{*}{ Father's occupation } & 0.163 & 0.0735 & 0.130 \\
\hline & $(0.369)$ & $(0.261)$ & $(0.336)$ \\
\hline \multirow[t]{2}{*}{ Mother's occupation } & 0.136 & 0.0619 & 0.109 \\
\hline & $(0.343)$ & $(0.241)$ & $(0.312)$ \\
\hline \multirow[t]{2}{*}{ Household size } & 3.973 & 4.648 & 4.217 \\
\hline & $(1.283)$ & $(1.342)$ & $(1.344)$ \\
\hline \multirow[t]{2}{*}{ \# old dependent } & 0.155 & 0.105 & 0.137 \\
\hline & $(0.424)$ & $(0.344)$ & $(0.398)$ \\
\hline \multirow[t]{2}{*}{ \# young dependent } & 0.813 & 0.717 & 0.779 \\
\hline & $(0.868)$ & $(0.825)$ & $(0.854)$ \\
\hline \multirow[t]{2}{*}{ Household land } & 4.870 & 5.835 & 5.219 \\
\hline & $(5.541)$ & $(4.532)$ & $(5.220)$ \\
\hline \multirow[t]{2}{*}{ Log(housing value) } & 10.31 & 10.10 & 10.23 \\
\hline & $(1.088)$ & $(0.981)$ & $(1.056)$ \\
\hline Observations & 9,537 & 5,393 & 14,930 \\
\hline
\end{tabular}

Source: RUMiC rural household survey 2007. Individuals aged 16 to 60 years (excluding current migrants in 2007). 
Table 6: Impact of migration on farm work participation - FIML estimation

Farm work participation for the left-behinds

\begin{tabular}{|c|c|c|c|c|c|c|}
\hline & \multicolumn{2}{|c|}{ Households with migrants } & \multicolumn{2}{|c|}{ Households with no migrants } & \multicolumn{2}{|c|}{ Selection equation } \\
\hline & Coefficient & Std error & Coefficient & Std error & Coefficient & Std error \\
\hline \multicolumn{7}{|l|}{ Individual characteristics } \\
\hline Male & 0.097 & 0.074 & -0.020 & 0.041 & $-0.302^{* * *}$ & 0.020 \\
\hline Age & $-0.078^{* * *}$ & 0.030 & $-0.073^{* * *}$ & 0.017 & $0.118^{* * *}$ & 0.012 \\
\hline Age squared & $0.0008^{* * *}$ & 0.0003 & $0.0009^{* * *}$ & 0.0002 & $-0.0011^{* * *}$ & 0.0001 \\
\hline Education & -0.017 & 0.011 & $-0.042^{* * *}$ & 0.008 & -0.005 & 0.007 \\
\hline Training & $-0.461^{* * *}$ & 0.091 & $-0.340^{* * *}$ & 0.051 & -0.056 & 0.042 \\
\hline Married & $0.213^{*}$ & 0.129 & $-0.189^{* *}$ & 0.086 & $-0.213^{* * *}$ & 0.066 \\
\hline Past ind. migration & $-0.546^{* * *}$ & 0.072 & $-0.591^{* * *}$ & 0.056 & $0.085^{* *}$ & 0.043 \\
\hline \multicolumn{7}{|l|}{ Household characteristics } \\
\hline Father's occupation & -0.029 & 0.137 & $-0.197^{* * *}$ & 0.074 & $-0.274^{* * *}$ & 0.072 \\
\hline Mother's occupation & -0.162 & 0.148 & -0.124 & 0.080 & $-0.265^{* * *}$ & 0.080 \\
\hline Household size & -0.118 & 0.110 & -0.041 & 0.054 & $0.508^{* * *}$ & 0.022 \\
\hline \# old dependent & 0.079 & 0.160 & $-0.170^{* *}$ & 0.084 & $-0.580^{* * *}$ & 0.060 \\
\hline \# young dependent & 0.155 & 0.105 & 0.062 & 0.052 & $-0.452^{* * *}$ & 0.029 \\
\hline Household land & $0.047^{* * *}$ & 0.010 & $0.051^{* * *}$ & 0.006 & 0.003 & 0.004 \\
\hline Log(housing value) & -0.0493 & 0.050 & $-0.143^{* * *}$ & 0.028 & $-0.160^{* * *}$ & 0.018 \\
\hline County dummies & Yes & & Yes & & & \\
\hline Constant & $4.214^{* * *}$ & 0.957 & $4.207^{* * *}$ & 0.385 & $-3.178^{* * *}$ & 0.283 \\
\hline \multicolumn{7}{|l|}{ Instrument } \\
\hline $\begin{array}{l}\text { Distance-weighted wage } \\
\text { at destination in } 2002\end{array}$ & & & & & $0.829^{* * *}$ & 0.254 \\
\hline$\rho_{\mu 1}$ & -0.296 & 0.386 & & & & \\
\hline$\rho_{\mu 0}$ & -0.165 & 0.188 & & & & \\
\hline Wald Chi2 & 1.30 & Prob $>$ Ch & $2=0.52$ & & & \\
\hline
\end{tabular}

Source: RUMiC Rural Household Survey 2007.

Notes: 12,154 observations, individuals aged 16 to 60 years. Log-likelihood: -12250.899. Standard errors are adjusted for clustering at the household level. ${ }^{*} p<0.10,{ }^{* *} p<0.05,{ }^{* * *} p<0.01$. 
Table 7: Impact of migration on wage work participation - FIML estimation

Wage work participation for the left-behinds

\begin{tabular}{|c|c|c|c|c|c|c|}
\hline & \multicolumn{2}{|c|}{ Households with migrants } & \multicolumn{2}{|c|}{ Households with no migrants } & \multicolumn{2}{|c|}{ Selection equation } \\
\hline & Coefficient & Std error & Coefficient & Std error & Coefficient & Std error \\
\hline \multicolumn{7}{|l|}{ Individual characteristics } \\
\hline Male & $0.548^{* * *}$ & 0.079 & $0.082^{* * *}$ & 0.032 & $-0.310^{* * *}$ & 0.019 \\
\hline Age & $0.108^{* * *}$ & 0.031 & $0.095^{* * *}$ & 0.012 & $0.115^{* * *}$ & 0.011 \\
\hline Age squared & $-0.001^{* * *}$ & 0.0003 & $-0.001^{* * *}$ & 0.0001 & $-0.001^{* * *}$ & 0.0001 \\
\hline Education & $0.048^{* * *}$ & 0.007 & $0.066^{* * *}$ & 0.0107 & -0.006 & 0.006 \\
\hline Training & $0.268^{* * *}$ & 0.042 & $0.257^{* * *}$ & 0.0427 & -0.056 & 0.042 \\
\hline Married & $-0.163^{* *}$ & 0.069 & -0.072 & 0.0669 & $-0.207^{* * *}$ & 0.064 \\
\hline Past ind. migration & $0.483^{* * *}$ & 0.049 & $0.492^{* * *}$ & 0.0542 & 0.046 & 0.043 \\
\hline \multicolumn{7}{|l|}{ Household characteristics } \\
\hline Father's occupation & 0.018 & 0.060 & 0.042 & 0.0637 & $-0.263^{* * *}$ & 0.070 \\
\hline Mother's occupation & -0.024 & 0.068 & $-0.116^{*}$ & 0.0677 & $-0.279^{* *}$ & 0.078 \\
\hline Household size & $0.271^{* * *}$ & 0.026 & $0.228^{* * *}$ & 0.0343 & $0.505^{* * *}$ & 0.021 \\
\hline \# old dependent & $-0.200^{* * *}$ & 0.056 & $-0.104^{* *}$ & 0.0534 & $-0.581^{* * *}$ & 0.058 \\
\hline \# young dependent & $-0.277^{* * *}$ & 0.031 & $-0.205^{* * *}$ & 0.0352 & $-0.450^{* * *}$ & 0.029 \\
\hline Household land & $-0.027^{* * *}$ & 0.05 & $-0.020^{* * *}$ & 0.0050 & 0.003 & 0.004 \\
\hline Log(housing value) & -0.022 & 0.022 & $0.054^{* * *}$ & 0.0211 & $-0.155^{* *}$ & 0.017 \\
\hline County dummies & Yes & & Yes & & & \\
\hline Constant & $-4.862^{* * *}$ & 0.928 & $-3.390^{* * *}$ & 0.328 & $-3.095^{* * *}$ & 0.278 \\
\hline \multicolumn{7}{|l|}{ Instrument } \\
\hline $\begin{array}{l}\text { Distance-weighted wage } \\
\text { at destination in } 2002\end{array}$ & & & & & $0.807^{* * *}$ & 0.255 \\
\hline$\rho_{\mu 1}$ & 0.030 & 0.243 & & & & \\
\hline$\rho_{\mu 0}$ & 0.893 & 0.031 & & & & \\
\hline Wald Chi2 & 85.56 & Prob $>\mathrm{Ch}$ & $\mathrm{i} 2=0.00$ & & & \\
\hline
\end{tabular}

Source: RUMiC Rural Household Survey 2007.

Notes:12,154 observations, individuals aged 16 to 60 years. Log-likelihood: -10842.151. Standard errors are adjusted for clustering at the household level. ${ }^{*} p<0.10,{ }^{* *} p<0.05,{ }^{* * *} p<0.01$. 
Table 8: Impact of migration on self-employment participation - FIML estimation

Self-employment participation for the left-behinds

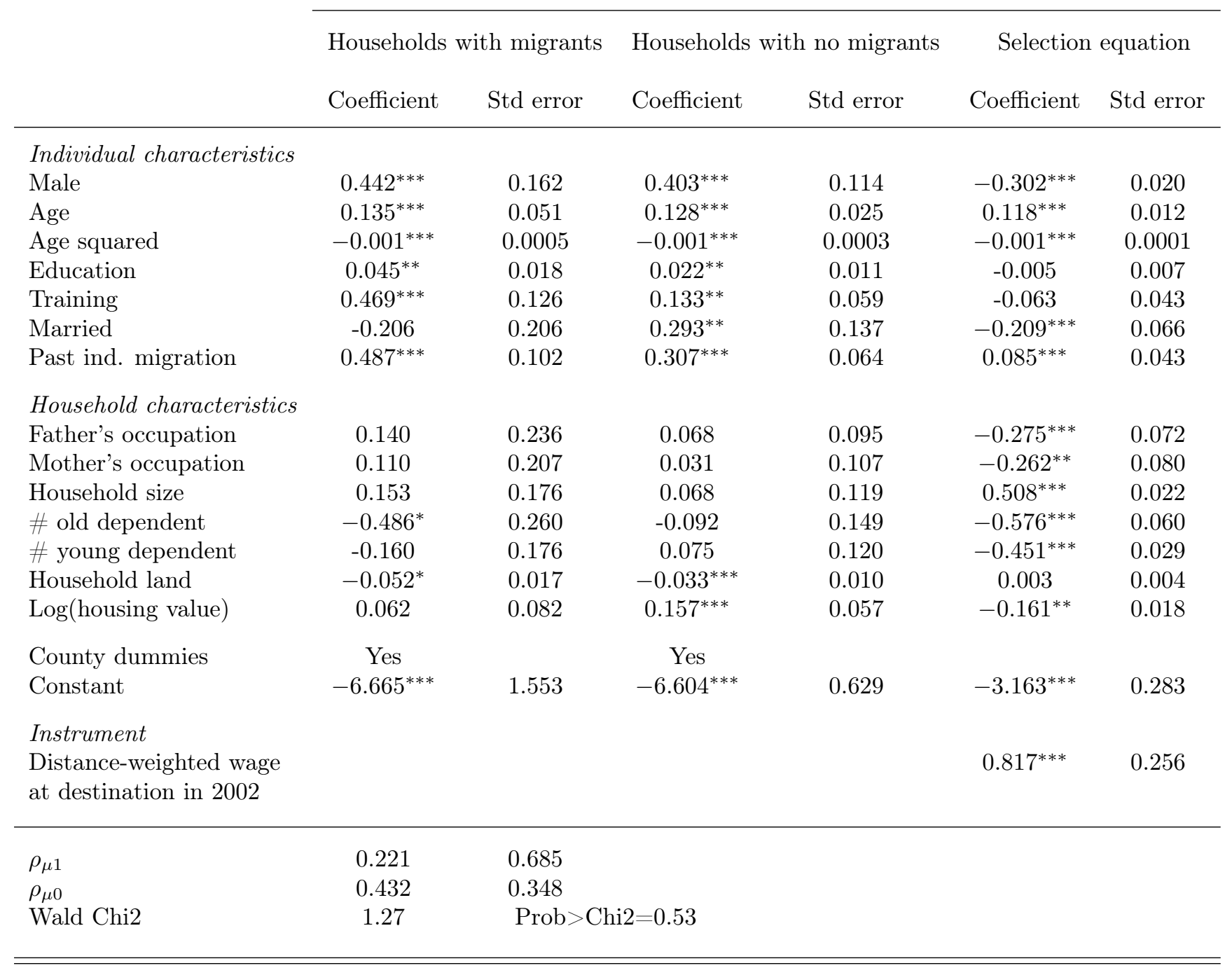

Source: RUMiC Rural Household Survey 2007.

Notes: 12,154 observations, individuals aged 16 to 60 years. Log-likelihood: -9098.4895. Standard errors are adjusted for clustering at the household level. ${ }^{*} p<0.10,{ }^{* *} p<0.05,{ }^{* * *} p<0.01$. 
Table 9: Impact of migration on housework participation - FIML estimation

Housework participation for the left-behinds



Source: RUMiC Rural Household Survey 2007.

Notes: 12,154 observations, individuals aged 16 to 60 years. Log-likelihood: -9528.0623. Standard errors are adjusted for clustering at the household level. ${ }^{*} p<0.10,{ }^{* *} p<0.05,{ }^{* * *} p<0.01$. 
Table 10: Estimated mean treatment parameters

\begin{tabular}{lcccc}
\hline \hline & Average treatment effect & Average treatment effect \\
& on the treated (ATT) & \multicolumn{2}{c}{ (ATE) } \\
& Estimate & Std error & Estimate & Std error \\
& & & & \\
& & & \\
Migrant sending households & 0.1548 & 0.0016 & 0.1970 & 0.0012 \\
Farm work participation & -0.6090 & 0.0019 & -0.2492 & 0.0013 \\
Wage work participation & -0.1560 & 0.0018 & -0.0865 & 0.0008 \\
Self-employment participation & -0.0050 & 0.0009 & -0.0085 & 0.0007 \\
Housework participation & & & & \\
Remittance-receiving households & & & & 0.0023 \\
Farm work participation & 0.0872 & 0.0029 & 0.0232 & 0.0026 \\
Wage work participation & -0.2938 & 0.0040 & -0.1270 & 0.0005 \\
Self-employment participation & -0.0355 & 0.0009 & -0.0203 & 0.0003 \\
Housework participation & 0.0216 & 0.0003 & 0.0008 & \\
Early-experienced migrant households & & & & 0.0015 \\
Farm work participation & -0.2952 & 0.0036 & -0.0589 & 0.0018 \\
Wage work participation & -0.5875 & 0.0046 & -0.2883 & 0.0008 \\
Self-employment participation & 0.0436 & 0.0012 & 0.0727 & 0.0005 \\
Housework participation & 0.0821 & 0.0011 & 0.0831 & \\
& & & & \\
\hline \hline
\end{tabular}

Source: RUMiC Rural Household Survey 2007.

Notes: Based on switching probit estimates for each participation choice and each selection type. Standard errors are calculated by bootstrapping with 200 replications. 
Figure 1: Occupation shares by age and by gender in 2007
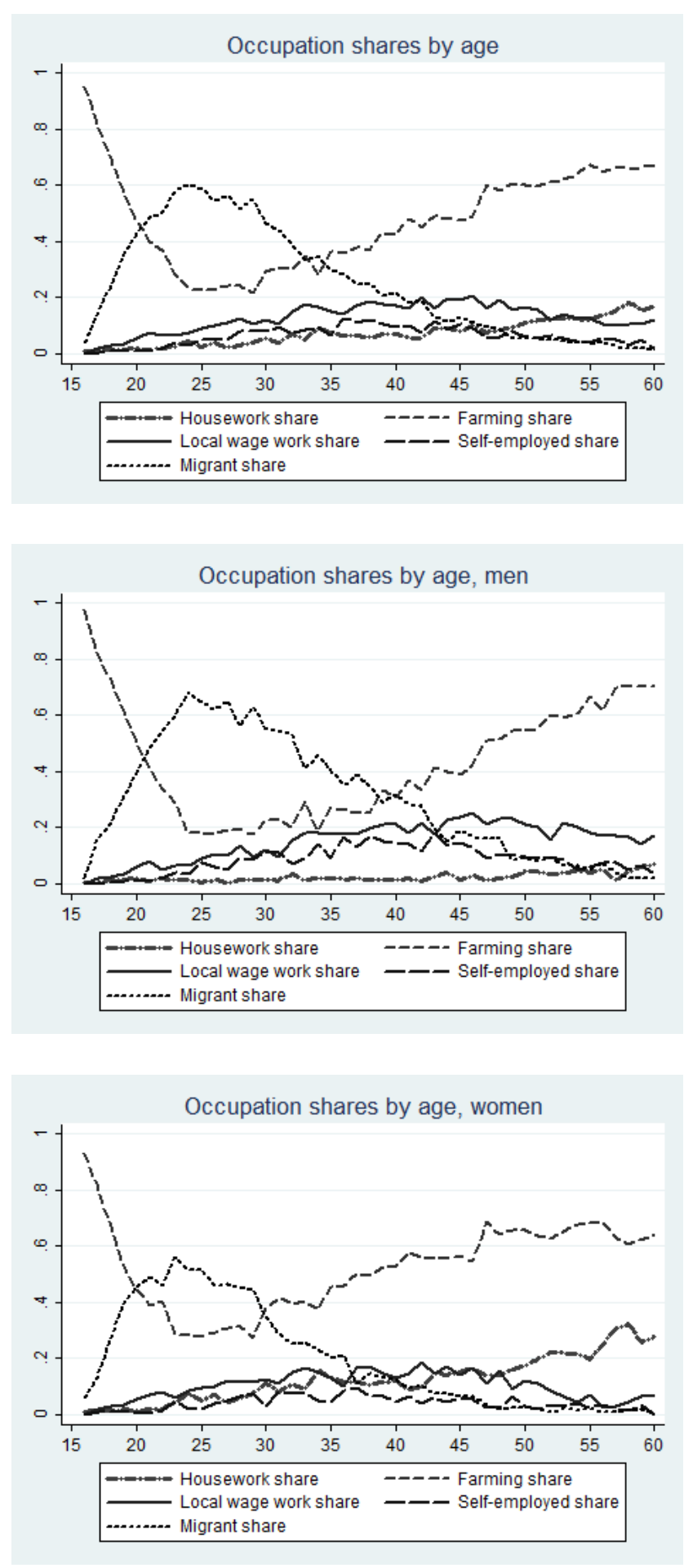